\title{
MARIKANA, A PAST NEVER TRULY ESCAPED: A CRITIQUE ON THE COMMODIFICATION OF THE LEGAL SYSTEM AND THE LAW AS AN INSTRUMENT OF JUSTICE IN POST-APARTHEID SOUTH AFRICA
}

by Vaughn Rajah*

\section{Introduction}

The 16th of August 2017 will mark the 5th year since South Africa's Marikana tragedy. In August of 2012, miners in the employment of one of South Africa's biggest platinum mines, situated in the mining town of Marikana and headed by Lonmin (a British mining company based in South Africa) initiated a strike for wage increases. A mere 6 days later, South African police fired live ammunition to violently halt the strikers, killing 44 workers in the process and injuring many more. ${ }^{1}$ It was the first recognised massacre in post-apartheid South Africa. In the aftermath, media and analysts labelled the event a 'turning point ${ }^{2}$ in South African history. This phrase implies a change, a deviation from the path previously trodden. A question arises on the notion of a turning point by considering the other ways in which impoverished black South Africans have historically been oppressed.

This article demonstrates that the Marikana tragedy was not a departure from the norm, but a continuation of state and corporate behaviour that has oppressed black South Africans for hundreds of years. This will be done through an analysis of the historically discriminatory socio-economic patterns of South African society, and how they subjugate the poor by limiting their access to legal and physical protection. These trends portray a history of commodification of the legal system. I discuss a notable documentary on the massacre, Miners Shot Down, and examine its depiction of the causes and effects of the events. The film provides no mention of the historical context of the killings, nor does it comment on many of the factors contributing to the massacre. Despite this, it succeeded in bringing the events to the attention of the broader public. I analyse the notions of justice, the rule of law and their application in South

* Second year LLB student, University of Pretoria.

1 N Buitendag \& N Coetzer 'History as system of wrongs - examining South Africa's Marikana tragedy in a temporal legal context' (2015) 37 Strategic Review for Southern Africa 94.

2 M Legassick 'South Africa: Marikana Massacre - a turning point?' 27 August 2012 http://links.org.au/node/3002 (accessed 21 August 2017). 
Africa as well as norms in the nation's legal culture. Additionally, I examine the Farlam Commission, and how its procedures and conclusions hindered the course of justice in the context of our democracy. Ultimately, I demonstrate how the Marikana massacre was not a change in dynamic, but a reminder of a past we have never truly escaped.

\section{Marikana in context: Historical state- corporate collusion and legal commodification}

My main argument, as stated, is that the Marikana killings were a pervasion of structural inequalities and systems of oppression that have existed in South African society for hundreds of years. The massacre itself occurred within an industry that has enjoyed financial success over a considerable period in South African history. ${ }^{3}$ Mining has a long tradition in the country. In 1867 diamonds were discovered in Kimberley. ${ }^{4}$ It was on these mines that the foundations for future discriminatory labour practices in South Africa were laid. With the tools of extraction being in the hands of white capitalists and government, black labourers were exploited and subjugated, so as to create a servile workforce and diminish illicit trade. ${ }^{5}$ Both of these results increased profitability. ${ }^{6}$ The socio-economic impact this had on black labourers was dire. Their families became dependent on the money earned on the mines, therefore workers remained migrant labourers until they could no longer work. ${ }^{7}$ This dependency on white capital led to a deepening poverty cycle amongst black labourers. ${ }^{8}$ This trend has been entrenched in our history for a very long time. These events served as a catalyst for the creation of conditions that make 'a Marikana' possible even in a non-racial democracy. This link between government and the corporate world, for better or worse, is undeniable throughout South African history. Not only during periods of colonisation and apartheid, but also when negotiations to end apartheid took place as well as post-1994. ${ }^{9}$ Pre-1994, systems of white dominance empowered white South Africans and impoverished black South Africans. ${ }^{10}$ Terreblanche asserts that this legacy of 'racial

3 R Ross A Concise history of South Africa (2008) 54-87.

4 R Turrell 'Diamonds mines and migrant labour in South Africa' in History Today (1980) 45

5 Turrell (n 4 above) 45-48.

6 As above.

$7 \quad$ L Callinicos Gold and workers (1980) 29.

8 Callinicos (n 7 above) 31.

9 R Hamann 'South Africa: The role of history, government, and local context' in W Fihlo \& S Idowu (eds) Global Practices of Corporate Social Responsibility (2009) 435-460

10 Consciousness Admin 'Book Review - Lost in Transformation - Sampie Terreblanche' 3 November 2014 http://consciousness.co.za/book-review-losttransformation-sampie-terreblanche/ (accessed 22 August 2017). 
capitalism,11 has not been adequately addressed and that corporations have always had an overwhelming influence on state policy and decisions. ${ }^{12}$ He argues that during transitional negotiations big business 'bought off' 13 the ANC to ensure that profitable arrangements could be made for both parties. ${ }^{14}$ The ANC allowed the unequal structures of land and capital ownership in the country to continue. ${ }^{15}$ Most relevant to Marikana, the ANC was influenced to dispense with its proposed policy of nationalising mines, banks and other key economic industries and institutions. ${ }^{16}$ In this way large corporations have been protected from paying their 'apartheid debt." 17 It is not a given that nationalisation would have led to an adequate restructuring of the economy. However, I would argue that what has actually transpired has made that task an even tougher one.

The pressures exerted on the post-apartheid political leadership by multinationals have led to the creation of an environment where these corporations are still able to profit at the expense of most of the population. ${ }^{18}$ This can be seen to have had a direct impact on why the Marikana workers were striking for wage increases. Platinum prices have increased by over $300 \%$ since the turn of the century. ${ }^{19}$ There was clearly enough money to contribute to worker wage increases. Instead, profits were directed back to the Lonmin head offices in London. ${ }^{20}$ Nicolson and Marinovich argue that the police clearly acted in the interests of big business and its associated political actors by firing live ammunition. ${ }^{21}$ This was done with the intention of halting the strike as soon as possible. ${ }^{22}$ Furthermore, quelling the strikes was an attempt to protect the profits of the company. This exhibited a complete disregard for the safety of the impoverished workforce. ${ }^{23}$ Due to special interest groups having such a large influence on government, combined with the poor's

11 As above.

12 As above.

13 P de Vos 'Some thoughts on the Marikana Massacre' 18 August 2012 https:// constitutionallyspeaking.co.za/some-thoughts-on-the-marikana-massacre/ (accessed 22 August 2017).

14 As above.

15 C Modisane 'How Mandela's ANC sold out the economic struggle' 22 April 2014 http://www.news24.com/ (accessed 21 August 2017).

16 Modisane (n 15 above).

17 de Vos (n 13 above).

18 Consciousness Admin (n 10 above).

19 Carolyn 'Sampie Terreblanche's Lost in Transformation looks at inequality in South Africa' 28 November 2012 http://bookslive.co.za/ (accessed 22 August 2017).

20 As above.

21 G Nicolson \& G Marinovich 'Marikana massacre: SAPS, Lonmin, Ramaphosa \& time for blood. Miners' blood' 24 October 2013 www.dailymaverick.co.za (accessed 21 August 2017).

22 As above.

23 As above. 
dependency on the state, the legal system has become commodified with the impoverished being treated as if they are beneath the law. ${ }^{24}$

In the documentary Miners Shot Down, on which I elaborate below, the AMCU leader implored the workers to cease strike action. The AMCU leader further stated that big business and the government had colluded to defeat the miners' plight, and worsen their current conditions, commenting 'the life of a black man is so cheap in South Africa. ${ }^{25}$ In essence, it required money to guarantee legal assistance. In a notable case, Jaftha $v$ Schoeman and Others, Van Rooyen v Stoltz and Others ${ }^{26}$ (where the law favoured the poor) attorneys seeking the houses of two poor parties, sold due to their defaulting on small loans, was ruled unconstitutional. However, instances of radical lawyers willing to fight for the poor are certainly not the South African norm. ${ }^{27}$ This inequality has led to strike-action becoming commonplace amongst the working class, who display a willingness to fight for their constitutional rights. ${ }^{28}$ Our Constitution seeks to redress imbalances of the past by promoting transformation above retribution, and justification over authority. ${ }^{29}$ Yet it is apparent that material redistribution has not been sufficient, ${ }^{30}$ and that a culture of authority was utilised in dealing with the Marikana protests. Even after the advent of democracy, and despite clear recent political and legal victories, economic realities have not changed in South Africa. ${ }^{31}$ From this, it is apparent that the Marikana tragedy was a continuation of historical systemic oppression in South African society.

\section{A brief analysis of Miners Shot Down}

The most well-known documentary on the massacre is the 2014 film Miners Shot Down by Rehad Desai. The film brought the events to the attention of the wider public, highlighting the police brutality and strong evidence of state collusion. ${ }^{32}$ By placing the killings in their historical context, the film falls short as it silences many of the factors contributing to, and that come about because of, the massacre. Schutte claims there is no mention of the white capitalist

24 S Zikode 'Poor People's Movements and the Law' 2 December 2011 http:// abahlali.org/node/8551/ (accessed 8 May 2017).

$25 \quad \mathrm{~N}$ Davies 'Marikana massacre: the untold story of the strike leader who died for workers rights' 19 May 2015 www.theguardian.com/world/2015/may/19/ marikana-massacre-untold-story-strike-leader-died-workers-rights (accessed 20 August 2017).

262005 (2) SA 140 (CC).

27 Zikode (n 24 above).

28 Zikode (n 24 above).

29 P Langa 'Transformative constitutionalism' (2006) 17 Stellenbosch Law Review 351-360.

30 As above.

31 Zikode (n 24 above).

32 G Nicolson "'Miners Shot Down": Still the film every South African should see' 5 August 2014 http://www.dailymaverick.co.za (accessed 8 May 2017). 
powers that were involved in the situation, neither was there a discussion regarding the plight of wives of mineworker families. ${ }^{33}$ । would agree with this assertion as the points that the film raises- the use of force by the police were excessive, and there is evidence pointing to the involvement of African National Congress (ANC) associates (particularly Cyril Ramaphosa) - are of importance. However, exclusively citing these factors holds the piece dangerously close to perpetuating an anti-black sentiment. ${ }^{34}$

Historical context is especially important in my opinion, because what is startling about the conditions encapsulated in the Marikana massacre is how similar they are to circumstances prevalent in South African society since 1652; unskilled black labourers being underpaid by white managers. Structurally, the Lonmin mining managers did not create family units and black labourers became migrants, leading to frustration amongst the workforce (this anger often conveys itself in the form of domestic violence against women as well as forcing women into prostitution to maintain the household while the men are away). ${ }^{35}$ This should have been highlighted in the film. Therefore, the causes and consequences of the killings can be analysed via the common-thread of the unequal and oppressive socio-economic conditions that have dominated South African labour patterns, and society at large throughout the nation's history.

\section{The role of South African legal culture}

In analysing the causes and consequences of Marikana, it is also important to examine the South African legal culture, as well as the interpretation of South African law employed in the aftermath of the killings. To do so a distinction must be made between a society governed by laws and a society governed by the rule of law. The law is a set of rules for society, designed to protect basic rights and freedoms, and to treat everyone fairly. ${ }^{36}$ The World Justice Project ${ }^{37}$ provides a comprehensive definition of the rule of law: The rule of law is a system of rules and rights that enables fair and functioning societies in which the following four universal principles are upheld:

(1) The government and its officials and agents, as well as individuals, and private entities are accountable under the law:

33 G Schutte “"Miners Shot Down” an unequal representation of the bigger picture' 22 August 2014 http://mg.co.za (accessed 1 June 2017).

34 As above,

35 M Dywili 'Marikana: Causes and effects' 2 April 2014 http://www.wri-irg.org (accessed 3 May 2017).

36 Organisation of American States 'What is the law?' https://www.oas.org/ juridico/mla/en/can/en_can_mla_what.html (accessed 20 May 2017).

37 World Justice Project 'What is the rule of law?' https://worldjusticeproject.org/ about-us/overview/what-rule-law (accessed 10 May 2017). 
(2) The laws are clear, publicized, stable and just; are applied evenly; and protect fundamental rights, including the security of persons and property;

(3) The process by which laws are enacted, administered and enforceable is accessible, fair and efficient;

(4) Justice is delivered in a timely fashion by competent, ethical, and independent representatives and neutrals that are of sufficient number, have adequate resources and reflect the makeup of the communities they serve.

Throughout history, there are many examples where the laws have not embraced the rule of law and have served to oppress, such as the 'Jim Crow' segregation laws in the United States and Zimbabwe's recent anti-gay laws. ${ }^{38}$ In listing such instances, Harman specifically refers to pre-1994 South African as a recognisable event in this regard. ${ }^{39}$ A state governed by laws without using the rule of law as a guiding principle has the potential to become a police state. ${ }^{40}$ Laws being uniform in their application is essential to their doing justice. ${ }^{41}$ Unequal protection constitutes injustice and injustice oppresses. ${ }^{42}$ Society must value persuasion over coercion in order to engender a culture of justification. ${ }^{43}$ It is well known, that the coercive elements of fear and force were favoured in the oppressive apartheid state. From this lens, South Africa can be considered a nation whose legal norms and culture have been historically informed by systems of exclusion and oppression. This culture is comparable with South Africa's historical labour patterns. If these practices were to persist into the 21st century, it would be evident as to how a tragedy such as Marikana would be able to occur.

The Marikana massacre, however, took place in post-apartheid South Africa. The nation today is consistently described as one that is working towards becoming a non-racial democracy. ${ }^{44}$ The Constitution of the Republic of South Africa, $1996^{45}$ is the supreme law of the South African post-apartheid legal order. ${ }^{46}$ The founding provisions of this document invoke the rule of law as a governing principle of South African society. ${ }^{47}$ If the 'new' South Africa has truly

J Harman 'The rule of law - law as an instrument of justice and a tool of oppression' 2014 http://www.federalcircuitcourt.gov.au/ (accessed 12 May 2017).

39 Harman (n 38 above) 4.

40 Harman (n 38 above) 2.

41 Harman (n 38 above) 4.

42 Harman (n 38 above) 6.

43 E Mureinik 'A bridge to where? Introducing the Interim Bill of Rights' (1994) 10 South African Journal on Human Rights 31-32.

$44 \mathrm{~J}$ Jeffery 'Our vision remains of a non-racial, united South Africa' 14 November 2016 http://anctoday.org.za/vision-remains-non-racial-united-south-africa/ (accessed 20 August 2017).

45 (the Constitution).

46 Sec 1 of the Constitution, 1996.

47 As above. 
transformed, and is informed by the rule of law, it would have imbibed a culture of justification. ${ }^{48}$ Elements of a dictatorship or police state should not be a present and hence the occurrence of a tragedy such as Marikana would be regarded as unthinkable. ${ }^{49}$ This was clearly not the case, and is proof of a clear disconnection between enacted legislation and the realities of South African society and the legal system that governs it. ${ }^{50}$ This has resulted in many of the aforementioned factors present in the apartheid state still being evident today. ${ }^{51}$ In light of this, it is important to examine the interpretation of South African law employed in the aftermath of the killings. The forum used has been informally named 'the Farlam Commission'.

\section{Aftermath: Assessing the Farlam Commission}

President Jacob Zuma appointed the Marikana Commission of Inquiry on 23 August 2012, and was headed by retired Supreme Court judge, Ian Farlam, its mandate was to investigate the incident and provide resolutions and recommendations. The South African apartheid and post-apartheid social justice landscapes are filled with 'commissions of inquiry.' While advantages of allowing greater participation aids in lessening the impact of legal commodification, as well as being able to provide a wider scope of recommendations, these findings remain mere recommendations. ${ }^{52}$ The evidence accumulated was vast, which culminated in investigating the five major actors of Lonmin, AMCU, NUM, SAPS and Others, four in loco investigations over 300 days yielded 39719 pages of evidence, ${ }^{53}$ enough for the miners' counsel to make an allegation of state collusion. Based on this, a wide array of recommendations were put forth to the Director of Public Prosecutions in the North-West Province, providing a mandate applying to all relevant actors. ${ }^{54}$ Yet, as is often the case with such tribunals, key political and corporate figures (including Deputy President Ramaphosa) were exonerated. Consequently, reparation suggestions are not enforceable in many instances. ${ }^{55}$

48 Langa (n 29 above) 351-360.

49 Harman (n 38 above) 2.

50 Zikode (n 24 above).

51 J Dana 'Post-apartheid, inequality still rules in South Africa' 25 October 2015 www. thenational.ae (accessed 21 August 2017).

52 D McKinley 'Commissions of Inquiry or Omission?' 14 April 2015 http:// sacsis.org.za (accessed 3 May 2017).

53 'Marikana Commission of Inquiry: Report on matters of public, national and international concern arising out of the tragic incidents at the Lonmin Mine in Marikana, in the North-West Province'.

54 Farlam Commission: Summary of the key findings and recommendations made by the Farlam Commission http://www.marikanajustice.co.za/wp-content/uploads/ 2016/10/Summary-of-the-Farlam-Commission-Report.pdf (accessed 5 May 2017).

55 G Nicolson 'Marikana report: Key findings and recommendations' 26 June 2015 http://www.dailymaverick.co.za (accessed 3 May 2017). 
Much like the results of the Truth and Reconciliation Commission, reparations are not guaranteed, and the findings of the committee are not binding. Prior to the massacre, the State declared the strike illegal, preventing access to justice in this regard. ${ }^{56}$ In addition, Legal Aid initially refused to provide funding for the miners' legal counsel, severely hindering efforts to make a case for the impoverished workforce. ${ }^{57}$ Although one could argue that the wider scope of the forum extended access to justice to a greater number of actors, this access firmly depends on availability of legal representation. ${ }^{58}$ From a social justice perspective, a criminal trial; where a charge is laid, a decision to prosecute is taken and (through the use of substantive and appropriate evidence) binding enforceable outcomes are obtained via the judgment (subject to appeal and/ or review). ${ }^{59}$ This would have been more in line with South Africa's post-apartheid constitutional mandate of transformative justice, based on material reparations. ${ }^{60}$ Justice for the oppressed and impoverished parties has yet to be delivered, while political and corporate figures have been exonerated. The Farlam Commission was thus another pervasion of South Africa's structural inequalities and systems of oppression.

\section{Conclusion}

From the above, it can be concluded that the Marikana massacre was not a diversion from the South African social norm. The massacre was rather a devastating flashpoint that reminds us all the systemic racism and structural inequalities that have oppressed black South Africans and been signatures of South African society for hundreds of years. It can be reasonably demonstrated that an analysis of prevailing discriminatory socio-economic trends in the country reveal the foundations for the conditions which led to the Marikana massacre and its subsequent effects. Additionally, an examination of our legal system unveils that the inextricable link between big business and government has led to a commodification of the law. This systemically hinders social justice, and calls for transformation as enshrined in our Constitution. Miners Shot Down, although a flawed and biased piece, succeeded in bringing the events to the attention of the wider public.

Although the Constitution declares that South African society is informed by the rule of law, this is not the case. According to universally accepted definitions of this concept, if this were a reality, the conditions needed for a tragedy such as Marikana to occur would

56 McKinley (n 52 above) (accessed 3 May 2017).

57 'Constitutional court clarifies the right to legal aid representation in commissions of inquiry' http://www.legal-aid.co.za/ (accessed 3 May 2017).

58 Zikode (n 24 above).

59 T Humby et al Introduction to Law and Legal Skills in South Africa (2012) 227-241

60 Langa (n 29 above) 351-360. 
not be present. The Farlam Commission was also, inevitably, a pervasion of South Africa's structural inequalities. With justice for the victims yet to be delivered, normal criminal procedure may have yet proved more effective in this regard. The tag-line in Miners Shot Down is 'South Africa will never be the same again." 61 I would argue that, from colonial South Africa to the present day, we have hardly changed.

61 S Vollenhoven 'Emmy for "Miners Show Down" doccie' http://www. thejournalist.org.za/spotlight/emmy-for-miners-shot-down-doccie-2 (accessed 16 October 2017). 